\title{
Macroparasite community in molluses of a tidal basin in the Wadden Sea
}

\author{
David W. Thieltges · Manuela Krakau • \\ Henrike Andresen · Silke Fottner · Karsten Reise
}

Received: 8 August 2005/Revised: 3 May 2006/ Accepted: 12 May 2006/ Published online: 15 June 2006

(C) Springer-Verlag and AWI 2006

\begin{abstract}
We provide a quantitative inventory of macroparasites in intertidal molluscs from a tidal basin in the Wadden Sea (eastern North Sea). Gastropods and bivalves contained a species rich macroparasite community consisting of trematodes ( 26 species), turbellarians (1), nematodes (1), copepods (2) and polychaetes (1) in 3,800 host individuals from 10 host species. Highest parasite burdens were observed in the gastropods Hydrobia ulvae and Littorina littorea and in the bivalves Cerastoderma edule and Mytilus edulis. In contrast, only one parasite species and no trematodes were found in Crepidula fornicata. The parasite community in the molluscs was similar to other Western European localities but some parasite species showed obvious differences, related to the large-scale distribution of intermediate and final hosts. Parasitism seems to be a common phenomenon in molluscs of the Wadden Sea and hence the detrimental effects observed in experiments can be expected to frequently happen in the field.
\end{abstract}

Keywords Trematodes $\cdot$ Nematodes $\cdot$ Copepods $\cdot$ Polydora ciliata $\cdot$ Parasitism · Intertidal · Wadden Sea · Gastropods · Bivalves

Communicated by H.-D. Franke.

D. W. Thieltges $(\bowtie) \cdot$ M. Krakau $\cdot$ H. Andresen ·

S. Fottner $\cdot$ K. Reise

Alfred Wegener Institute for Polar and Marine Research,

Wadden Sea Station Sylt, Hafenstrasse 43, 25992 List,

Germany

e-mail: dthieltges@awi-bremerhaven.de

\section{Introduction}

Parasites of intertidal organisms are known to exert a variety of negative effects on their hosts, e.g. altering survival, condition and growth, constituting a pervasive population and community factor in intertidal ecosystems (Sousa 1991; Mouritsen and Poulin 2002). Although ecologically important, there is still little quantitative information available on the abundance and distribution of parasites in intertidal hosts. What is also largely lacking is information on the parasite community composition over a range of species within single intertidal ecosystems. Only a very few studies on parasites in coastal ecosystems have considered such a larger scale (de Montaudouin et al. 2000; Zander and Reimer 2002) and for the majority of coastal ecosystems and host taxa there is no such information available. This clearly hampers our understanding of the relative importance of parasites in intertidal ecosystems and on potential complex interactions between host and parasite communities.

This is also true for the extensive tidal flats of the Wadden Sea in northern Europe. Although parasite species have been described from a variety of intertidal hosts (e.g. Loos-Frank 1967, 1971a; Lauckner 1971), quantitative information is scarce. For some host species, quantitative accounts are available (e.g. Werding 1969; Buck et al. 2005) but up to now a quantitative inventory is lacking for most species and the total system, although Wadden Sea parasites have been described to severely affect their hosts (e.g. Mouritsen and Jensen 1994; Wegeberg and Jensen 1999; Thieltges 2006, in press).

In this study, we provide quantitative data on the parasite community composition in molluscs which as a 
group dominate the biomass in the intertidal sedimentary environment of the Wadden Sea. We aim to evaluate how common the phenomenon of parasitism is in molluscs of Wadden Sea tidal flats by (1) producing a species list of macroparasites and (2) giving a quantification of infection levels.

\section{Methods}

Study area

All samples were taken in the western part of the List tidal basin in the northern Wadden Sea (Fig. 1). This basin of $407 \mathrm{~km}^{2}$ is barred against the open sea by the islands of Sylt and $\mathrm{R} \emptyset \mathrm{m} \emptyset$ which are connected by causeways to the mainland. Tides enter the basin via a $2.8 \mathrm{~km}$ wide tidal inlet and are semidiurnal with a mean range of $2 \mathrm{~m}$. Salinity remains close to $30 \mathrm{psu}$. Mean water temperature is $15^{\circ} \mathrm{C}$ in summer and $4^{\circ} \mathrm{C}$ in winter. Tidal flats comprise $33 \%$ of the area with sand being the prevailing sediment type (72\%) followed by muddy sand (25\%) and mud (3\%). Dominant biota in the intertidal zone are Arenicola marina flats (66\%) and Zostera spp. meadows (12\%). Dominant bivalves on sand flats are Cerastoderma edule, Macoma balthica,
Mya arenaria and Ensis (directus) americanus, dominant gastropods are Hydrobia ulvae and Littorina littorea. Mussel beds (Mytilus edulis) cover approximately $3 \%$ of the intertidal area. Besides mussels, the bivalve Crassostrea gigas and the gastropods L. littorea and Crepidula fornicata are common on these beds. Cerastoderma glaucum is confined to a saltmarsh creek in the North of the island. For further information on the area see Gätje and Reise (1998).

\section{Data collection}

Only adult host individuals (according to size at maturity known from local studies (D. W. Thieltges et al., unpublished data), Table 1) were collected since some parasites are known to occur only in mature molluscs. Specimens from mussel beds were within sites randomly collected during low tide, specimens from sand or muddy sand flats were randomly collected by taking cores and sieving the sediment or by digging in case of deep burrowing species (Ensis (directus) americanus, $M$. arenaria). The sampling sites are shown in Fig. 1 and the sizes of investigated hosts as well as sampling effort are detailed in Table 1.

In the laboratory, gastropod tissues were removed from the shell and dissected. Bivalve tissues (and the
Fig. 1 Study area in the List tidal basin in the Wadden Sea (North Sea). Shaded areas indicate the intertidal. Black dots mark sites where host species (see abbreviations in figure) were sampled in recent years (97-04:19972004)

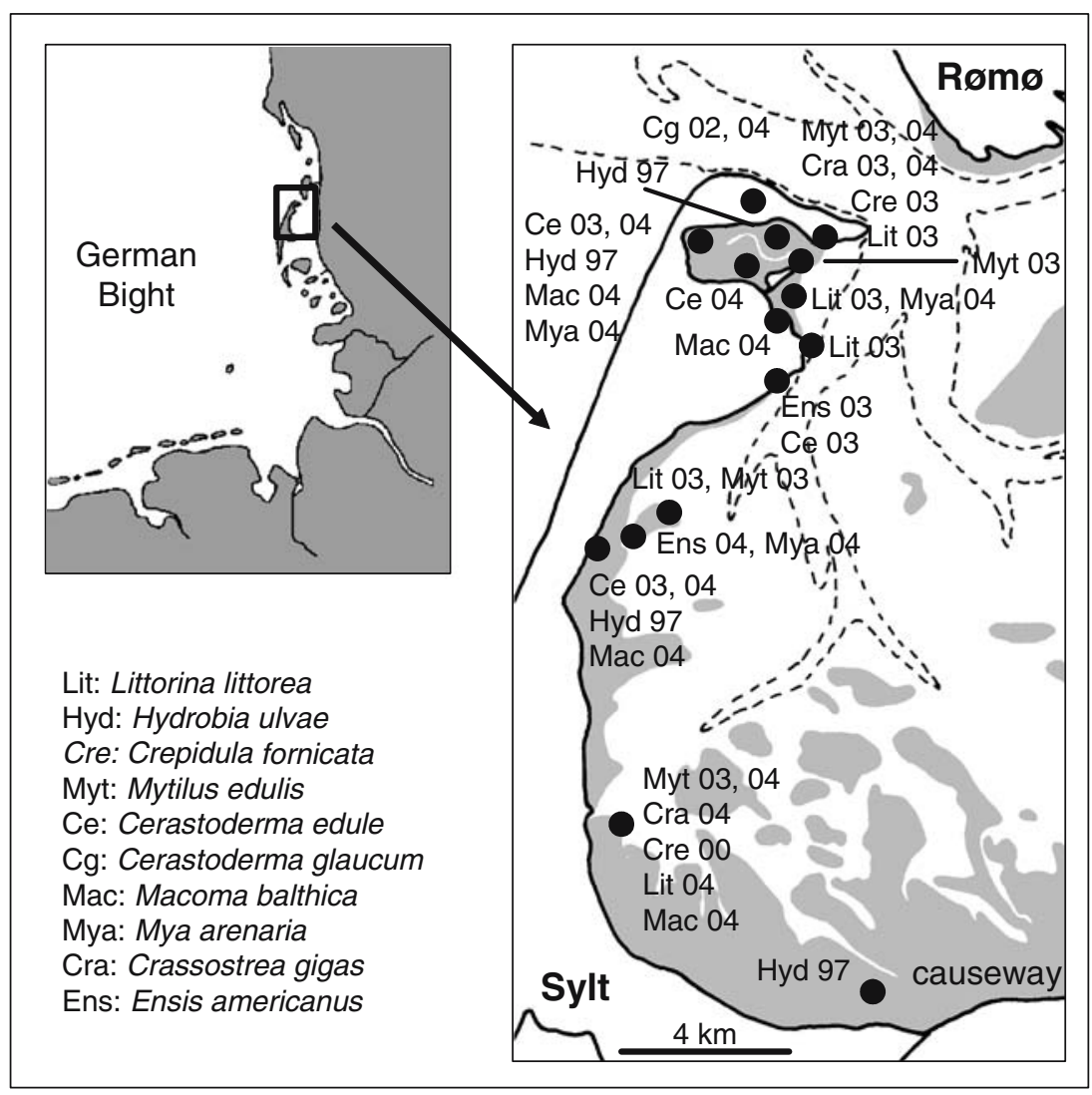


Table 1 Size of investigated mollusc host species, year of sampling, number of sites sampled and sampling effort per site and in total

\begin{tabular}{|c|c|c|c|c|c|}
\hline Host species & $\begin{array}{l}\text { Size } \\
(\mathrm{mm})\end{array}$ & $\begin{array}{l}\text { Year of } \\
\text { sampling }\end{array}$ & $\begin{array}{l}\text { No. sampling } \\
\text { sites }\end{array}$ & $\begin{array}{l}\text { No. host ind. } \\
\text { sampled } \\
\text { per site }\end{array}$ & $\begin{array}{l}\text { Total no. } \\
\text { host ind. } \\
\text { investigated }\end{array}$ \\
\hline Hydrobia ulvae & $>2$ & 1997 & 4 & $363-470$ & 1,681 \\
\hline Littorina littorea & $>14$ & 2003,2004 & 6 & $150-200$ & 1,090 \\
\hline Crepidula fornicata & $20-45$ & 2000,2003 & 2 & $54-70$ & 124 \\
\hline Cerastoderma edule & $21-47$ & 2003, 2004 & 6 & $20-54$ & 220 \\
\hline Mytilus edulis & $15-77$ & 2003, 2004 & 6 & $30-54$ & 234 \\
\hline Macoma balthica & $10-23$ & 2004 & 4 & $16-96$ & 167 \\
\hline Cerastoderma glaucum & $20-45$ & 2002, 2004 & 2 & $30-32$ & 62 \\
\hline Mya arenaria & $30-107$ & 2004 & 3 & $18-22$ & 60 \\
\hline Ensis americanus & $64-162$ & 2003,2004 & 2 & $4-40$ & 44 \\
\hline Crassostrea gigas & $28-158$ & 2003, 2004 & 3 & $20-54$ & 104 \\
\hline
\end{tabular}

"Sites" here also includes collections at the same locality but different years (see Fig. 1)

sample of C. fornicata from 2000 and approx. $20 \%$ of the other two gastropods) were removed from the valves and squeezed between two glass slides. Polydora ciliata infections were noted by investigating the individual shells. All dissections and observations were performed under a stereomicroscope. Parasite species were identified according to: Yamaguti 1958; Ankel 1962; Loos-Frank 1967, 1968, 1969, 1970, 1971b; Werding 1969; Reimer 1970; Lauckner 1971, 1980, 1983; Maillard 1975; Yamaguti 1975; Sannia et al. 1978; Deblock 1980; Bowers et al. 1996; Bartoli et al. 2000. For trematodes utilizing molluscs as first intermediate hosts and $P$. ciliata only presence/absence was recorded. For all other parasites numbers of individuals per host were determined.

Data analysis

Mean prevalence (\% infected individuals from total sample) of a parasite species in each host species was determined from prevalences within the investigated size groups at single sites. Mean intensities (mean number of parasites per infected hosts) for a parasite species in each host species were calculated by using data only from sites where a parasite species was present. In addition, mean total trematode prevalence per host species (\%) was determined: a mean total trematode prevalence per site was calculated by considering all trematode species found in single hosts; then the mean $( \pm \mathrm{SD})$ for all sites was determined. Mean total trematode intensity per host species was computed similarly: a mean total trematode intensity per site was calculated by summing up all trematode metacercariae (regardless of species identity) within single hosts; then the mean $( \pm \mathrm{SD})$ for all sites was determined.

\section{Results}

Macroparasite community

In the investigated molluscs $(3,800$ ind. from 10 species) we found 31 taxa of macroparasites, consisting of trematodes, copepods, nematodes, turbellarians and polychaetes (Table 2, Fig. 2). Some parasite species only occurred in a single host species while others were present in several hosts (Table 2). Parasites occurring in more than five host species were the trematodes Himasthla elongata, H. continua, H. interrupta, Renicola roscovita and Psilostomum brevicolle. Highest parasite burdens were observed in the gastropods $H$. ulvae and L. littorea and in the bivalves C. edule and M. edulis (Fig. 2, 3).

Trematodes

The dominant parasite group concerning numbers of species were trematodes (26 species) (Fig. 2). Gastropods were utilized by trematodes as first intermediate hosts by developing sporocysts/rediae in the gonads and visceral mass (Table 3). In some cases, gastropods also serve as second intermediate host when cercariae stay in the first intermediate host and develop into metacercariae (Microphallus pygmaeus, Psilochasmus aglyptorchis) (Table 3). Cercariae intended to infect a second intermediate bivalve host (e.g. Renicola roscovita) might also infect the original first intermediate gastropod host. The resulting metacercarial infections of gastropods were occasionally observed but were not included in the analysis since bivalves were clearly more important as second intermediate hosts (Table 3). Bivalves can also serve as first intermediate hosts but are more commonly used as second 


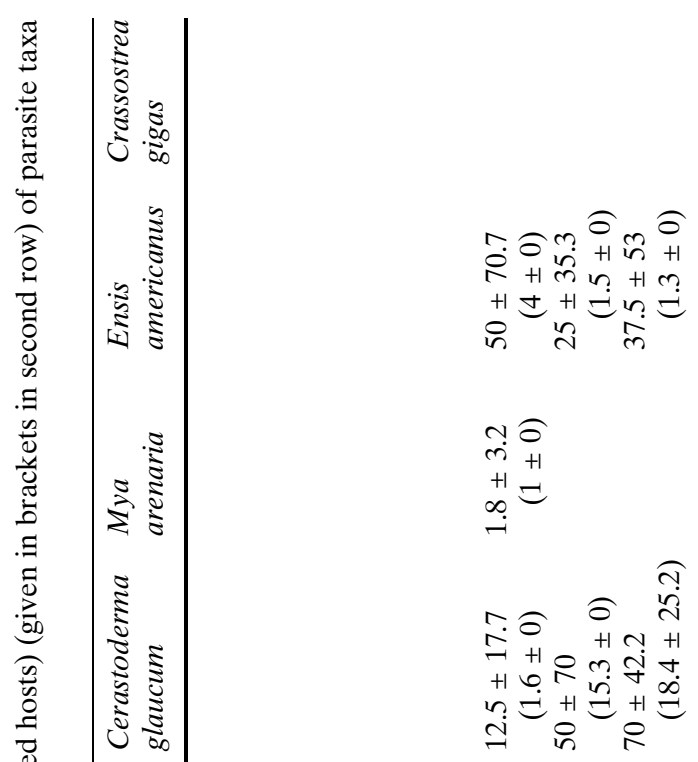

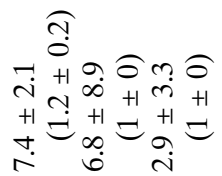

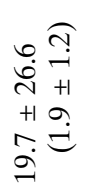

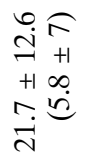

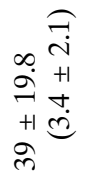

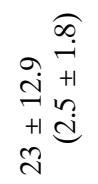

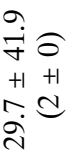

\begin{tabular}{c}
$n$ \\
\hdashline \\
8 \\
+1
\end{tabular} +े
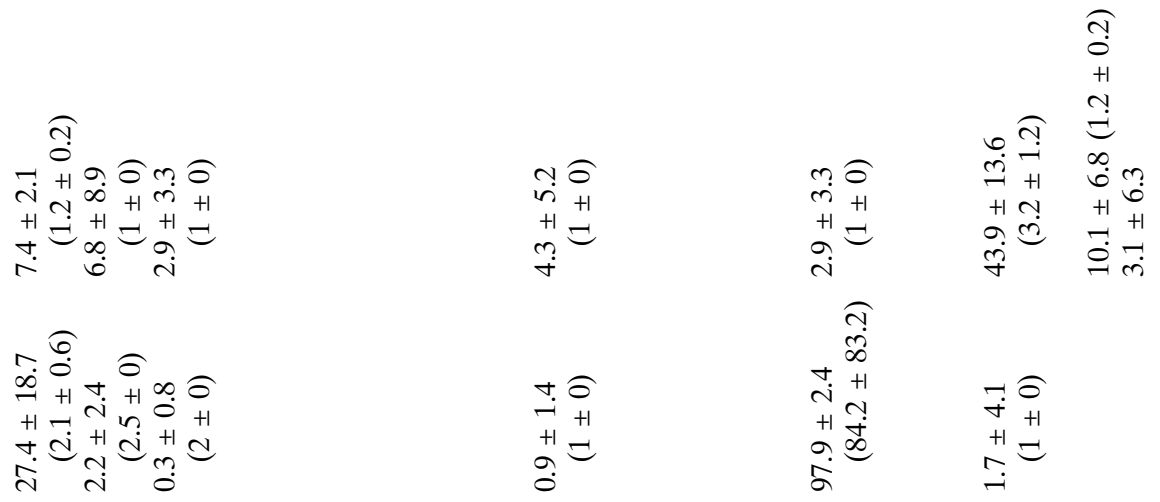

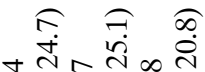

$\dot{\overrightarrow{4}}+1 \dot{m}+1 \infty \dot{m}+1$

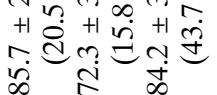

$\stackrel{\partial}{+}$
$\stackrel{0}{+}+1$
$\stackrel{+}{+}=$

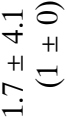

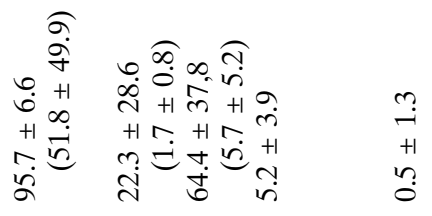

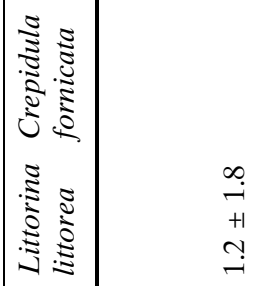

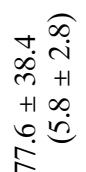

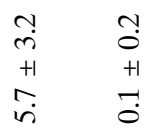

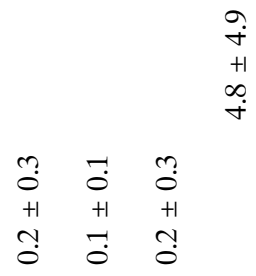

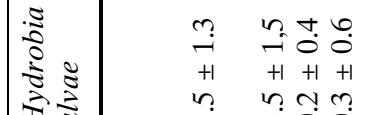

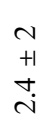

0
0
0
+1
+1
0
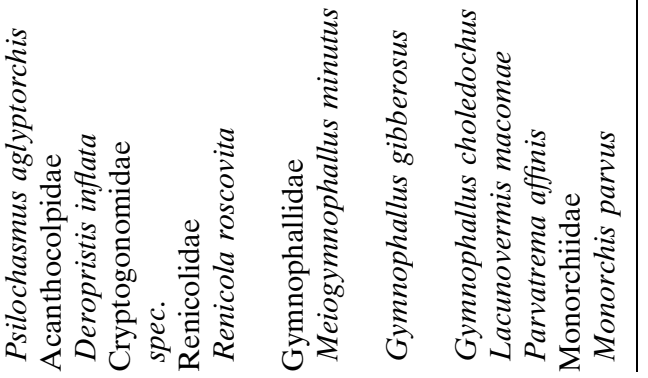


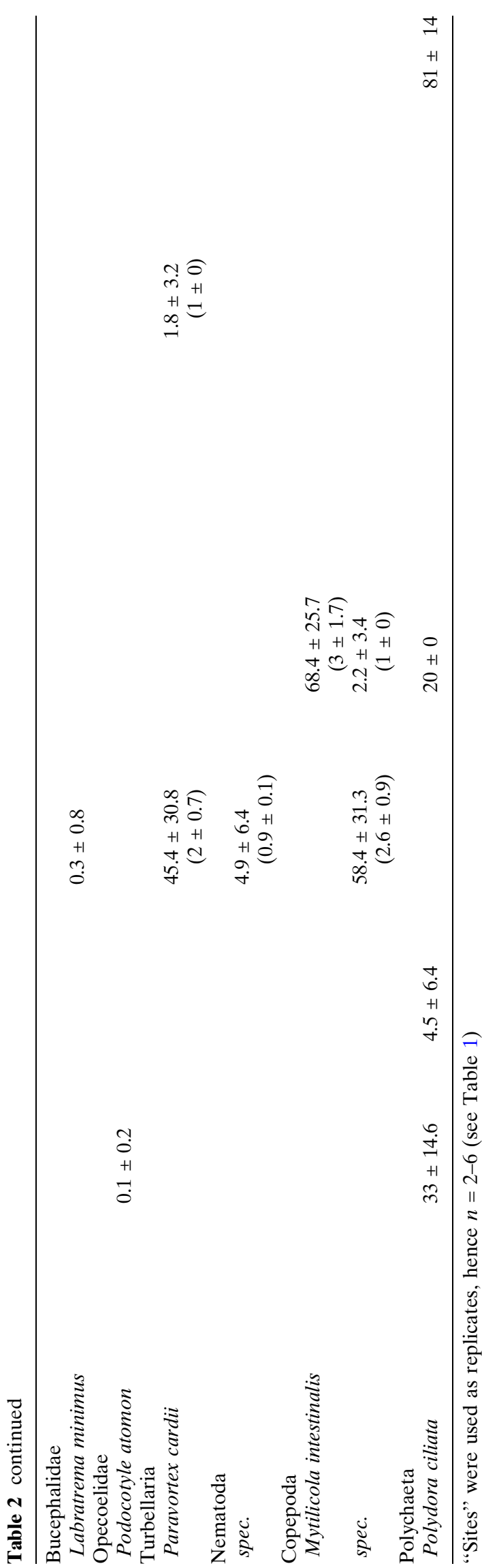

intermediate host (Table 3). Neither gastropods nor bivalves serve as final hosts which are known to be vertebrates like birds, fish or seals (Table 3 ).

In the two trematode harbouring gastropods, serving as first intermediate host, around $10 \%$ of individuals were infected by parasites (Fig. 3). In bivalves, mainly serving as second intermediate host, a higher proportion of individuals were infected with trematodes. All individuals of C. edule and $99 \%$ of the investigated M. edulis were infected by trematodes and total prevalences in all other bivalves were at least 22\% (Fig. 3). While the dominance of these two host species was reflected in the mean total intensity of metacercarial infections with $C$. edule and $M$. edulis harbouring over 85 ind./host, all other bivalves showed much lower total intensities in trematode infections (Fig. 3).

Non-trematodes

Compared to trematodes, non-trematode parasites were present in much lower numbers (five taxa) (Table 2). Although they could gain high prevelances, intensities were generally very low ( $<3$ ind./host) (Table 2). Some of these parasites were only found in single host species: nematodes of unknown identity in the tissue of $C$. edule and the copepod Mytilicola intestinalis in M. edulis. Turbellarians were mainly found in $C$. edule but also occurred in a few cases in $M$. arenaria. Copepods of unknown identity were observed in the mantle cavities and tissue of $C$. edule and $M$. edulis. The shell boring polychaete $P$. ciliata was present in the shells of L. littorea, C. fornicata, M. edulis and C. gigas.

\section{Discussion}

Parasite community composition

Parasitism seems to be a common phenomenon in molluscs of the Wadden Sea. In total, 31 parasite taxa were observed in the 10 species of mollusc hosts and hence the number of parasite taxa was three times higher than the species number of their hosts. With 26 species, trematodes were the dominant parasite group. Such a high diversity of trematode parasites seems likely due to the high abundance of intermediate as well as final hosts in the Wadden Sea. The complex life cycles of trematodes can easily be completed and this results in a high parasite load in mollusc intermediate hosts, as shown in this study, but also in bird final hosts (Loos-Frank 1971c; Borgsteede et al. 1988; Thieltges et al. 2006). 
Fig. 2 Number of parasite taxa found in the most abundant mollusc host species of the List tidal basin in the Wadden Sea (North Sea), differentiated by parasitic groups

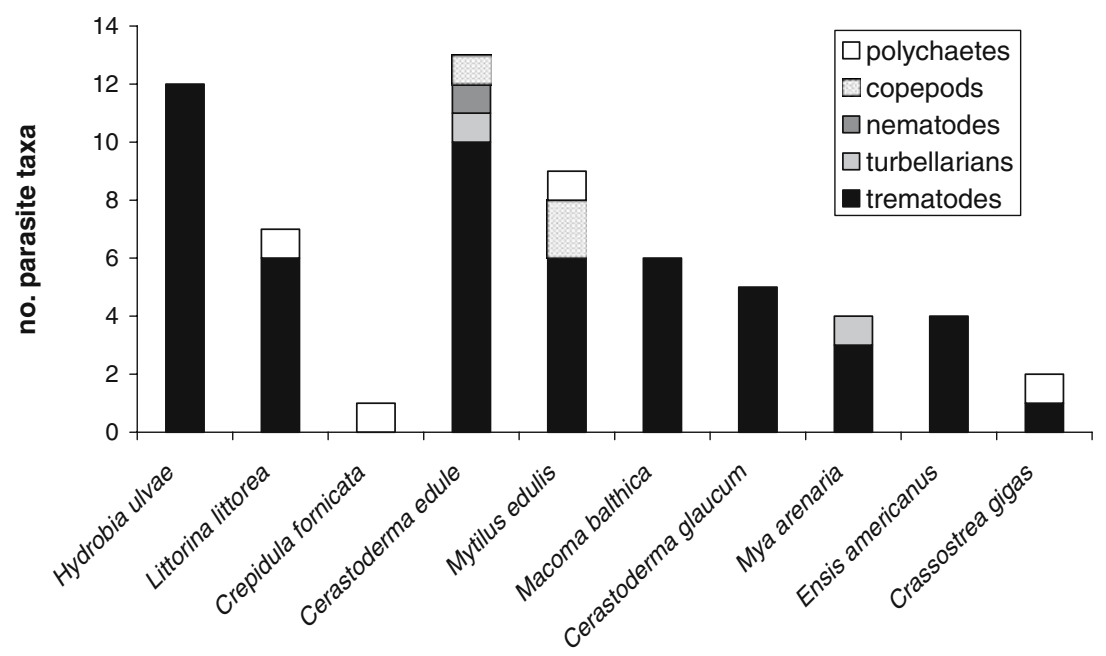

Fig. 3 Mean total prevalence + SD (\% infected ind. from total sample) of trematode infections and mean total intensity $+\mathrm{SD}$ (number parasite ind. per infected host) of metacercarial trematode stages in mollusc host species. For the three gastropods, only trematodes utilizing gastropods as first intermediate hosts were considered. "Sites" were used as replicates, hence $n=2-6$ (see Table 1). $x$ not determined
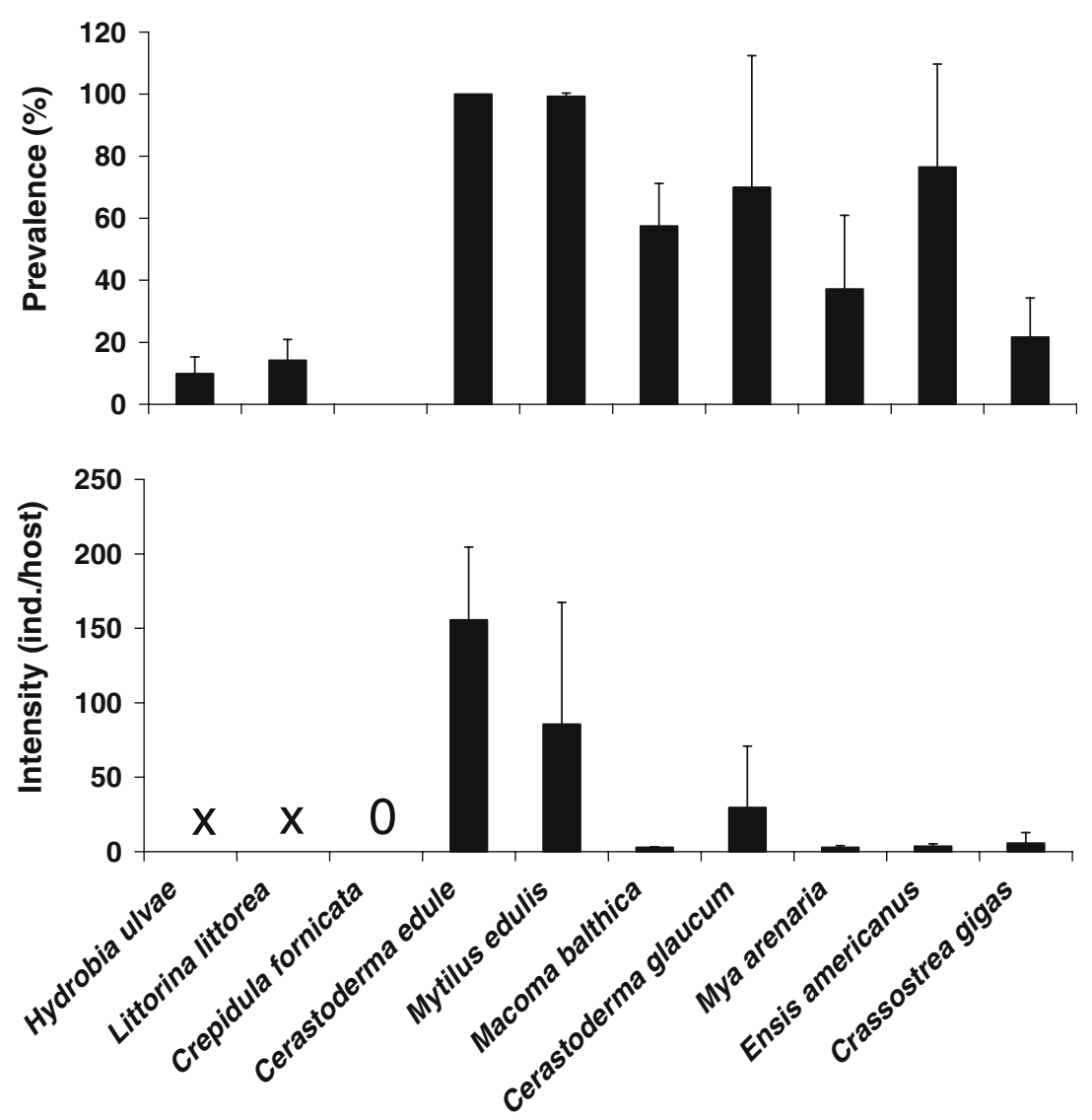

The use of various groups of organisms as hosts at different developmental stages results in a complex web of interactions between trematode parasites and their hosts (Table 3 ). Since final hosts are always vertebrates, the effects ascend to the top of the food web. For a complete quantitative parasite inventory of the system, crustaceans and other second intermediate hosts await investigation. Also for mollusc host, the trematode species spectrum within the system may not be complete since only the most abundant mollusc host species were investigated. In addition, some of our host species were sampled in relatively low numbers thus increasing the risk of missing rare parasite species (Gregory and Blackburn 1991). However, in terms of total parasite individuals present in the system the parasite species observed in our study are certainly the dominant ones. 
Table 3 Intermediate and final hosts of trematode species found in the molluscs of the List tidal basin

\begin{tabular}{|c|c|c|c|}
\hline Trematode species & 1st int. hosts & 2nd int. host & Final host \\
\hline \multicolumn{4}{|l|}{ Microphallidae } \\
\hline Microphallus claviformis & Hydrobia & Crustaceans & Birds \\
\hline Microphallus pygmaeus & Littorina & Littorina $^{\mathrm{a}}$ & Birds \\
\hline Maritrema subdolum & Hydrobia & Crustaceans & Birds \\
\hline Maritrema gratiosum & Hydrobia & Crustaceans & Birds \\
\hline Levinseniella brachysoma & Hydrobia & Crustaceans & Birds \\
\hline \multicolumn{4}{|l|}{ Echinostomatidae } \\
\hline Himasthla elongata & Littorina & Bivalves & Birds \\
\hline Himasthla continua & Hydrobia & Bivalves & Birds \\
\hline Himasthla interrupta & Hydrobia & Bivalves & Birds \\
\hline \multicolumn{4}{|l|}{ Heterophyidae } \\
\hline Cryptocotyle concavum & Hydrobia & Fish & Birds, seals \\
\hline Cryptocotyle jejuna & Hydrobia & Fish & Birds, seals \\
\hline Cryptocotyle lingua & Littorina & Fish & Birds, seals \\
\hline \multicolumn{4}{|l|}{ Notocotylidae } \\
\hline Cercaria ephemera & Hydrobia & None $^{\mathrm{b}}$ & Birds \\
\hline Cercaria lebouri & Littorina & None $^{b}$ & Birds \\
\hline \multicolumn{4}{|l|}{ Psilostomatidae } \\
\hline Psilostomum brevicolle & Hydrobia & Bivalves & Birds \\
\hline Psilochasmus aglyptorchis & Hydrobia & Hydrobia ${ }^{\mathrm{a}}$ & Birds \\
\hline \multicolumn{4}{|l|}{ Acanthocolpidae } \\
\hline Deropristis inflata & Hydrobia & Polychaetes & Fish \\
\hline \multicolumn{4}{|l|}{ Cryptogonomidae } \\
\hline spec. & Hydrobia & Probably fish & Probably fish \\
\hline \multicolumn{4}{|l|}{ Renicolidae } \\
\hline Renicola roscovita & Littorina & Bivalves & Birds \\
\hline \multicolumn{4}{|l|}{ Gymnophallidae } \\
\hline Meiogymnophallus minutus & Scrobicularia & Bivalves & Birds \\
\hline Gymnophallus gibberosus & Macoma & Bivalves & Birds \\
\hline Gymnophallus choledochus & Cerastoderma & Cerastoderma $a^{\mathrm{a}}$ or polychaetes & Birds \\
\hline Lacunovermis macomae & Macoma & Macoma & Birds \\
\hline Parvatrema affinis & Macoma & Macoma $^{\mathrm{a}}$ & Birds \\
\hline \multicolumn{4}{|l|}{ Monorchidae } \\
\hline Monorchis parvus & Cerastoderma & Cerastoderma ${ }^{\mathrm{a}}$ & Fish \\
\hline \multicolumn{4}{|l|}{ Bucephalidae } \\
\hline Labratrema minimus & Cerastoderma & Fish & Fish \\
\hline \multicolumn{4}{|l|}{ Opecoelidae } \\
\hline Podocotyle atomon & Littorina & Crustaceans & Fish \\
\hline
\end{tabular}

${ }^{a}$ Cercariae develop into metacercariae in the same host individual

${ }^{\mathrm{b}}$ Cercariae encyst outside the host

Data from: Loos-Frank 1967, 1968, 1969, 1970, 1971a, b; Werding 1969; Reimer 1970; Lauckner 1971, 1980, 1983; Maillard 1975; Sannia et al. 1978; Deblock 1980; Bowers et al. 1996; Bartoli et al. 2000

There are only a few scattered earlier studies on parasites in molluscs of the Wadden Sea, all concerned with single host species and their parasites and gathered in different parts of the Wadden Sea (e.g. Werding 1969; Lauckner 1971; Hulscher 1973; Swennen and Ching 1974; Michaelis 1978; Jensen and Mouritsen 1992; Mouritsen and Jensen 1994). Our study is the first to compile a parasite species inventory from the 10 most common mollusc species in the same system and it investigates some hosts for the first time in the Wadden Sea. Most parasite species seem to have been known from the area before but two species are likely to be newcomers: the trematodes Labratrema minimus and Monorchis parvus. Both species utilize fish as intermediate and/or final hosts and are well known in Mediterranean, French Atlantic and British waters (Maillard 1975; Sannia et al. 1978). Changing fish distributions and migrations during the last 30 years (Ehrich and Stransky 2001; Perry et al. 2005) may have carried the parasites into the Wadden Sea region.

Quantitative studies on parasites in mollusc communities from other Western European intertidal localities are extremely rare. A well-studied example comes from a bay at the Atlantic coast of France where de Montaudouin et al. (2000) investigated a bivalve community and found 12 macroparasite species in the three dominant host species, indicating a similar parasite/host-species ratio. From studies on parasite 
communities within single host species we can infer that similar parasite species (trematodes as well as nontrematodes) occur in the same host species along the Western European coast (see reviews by Cheng 1967; Lauckner 1980, 1983; Sindermann 1990). The obviously wide geographic distribution of most parasite species along European coasts is possibly linked to long-distance migrations of the vertebrate final hosts in case of trematodes and dispersal by ocean currents in nontrematode species. However, although a typical Wadden Sea fauna or even endemic species do not seem to exist, some parasite species show obvious differences between Western European coastal localities. These differences seem to be largely related to the distribution of intermediate and final hosts. Labratrema minumus is more common in the south, where its final fish hosts are also more abundant (Maillard 1975) and it may have recently invaded the Waden Sea by migration of its final hosts (see above). While very common in French waters (de Montaudouin et al. 2000; Desclaux et al. 2004), the trematode Himasthla quissetensis is absent from the Wadden Sea, possibly due to the lack of its first intermediate hosts, the gastropods Nassarius reticulates and Cyclope neritea. In contrast, Renicola roscovita seems to be more common in the northern Wadden Sea compared to France (de Montaudouin et al. 2000). Again this is probably linked to the distribution of the first intermediate host, L. littorea, which is more common in the Wadden Sea compared to French waters (de Montaudouin et al. 2000). However, differences in parasite communities along a Western European coastal north-south gradient deserve more detailed studies and should ideally be studied by investigating parasite loads of the same host species along the gradient.

Parasite communities in host species

All hosts species contained at least one parasite taxon and infection levels were often high. Highest parasite burdens were observed in the gastropods $H$. ulvae and L. littorea and in the bivalves $C$. edule and M. edulis. The high burden in these host species may result from a high susceptibility to parasites. However, the four host species are also the most abundant and widely distributed ones on the regional tidal flats (Reise 1985; Reise et al. 1994). Hence, high parasite diversity and infection levels may also reflect a high chance of an abundant host species to be exposed to infective stages.

One species, $C$. fornicata, was not infected by trematodes at all. Interestingly, this introduced species was also found to be free of trematode parasites in its native range (Pechenik et al. 2001). The underlying mechanism is not known but the extensive mucus produced by the snails for their filter apparatus might hinder infective stages in entering the host tissues by trapping and immobilizing cercarial infective stages. The other introduced species, C. gigas and Ensis (directus) americanus and presumably also $M$. arenaria (Reise et al. 1999; Strasser 1999) showed relatively low infection levels and this may be an example of the enemy release hypothesis (Torchin et al. 2002; Colautti et al. 2004; Krakau et al. 2006).

\section{Relevance of parasites}

The results indicate that parasites of molluscs add a hidden diversity to the benthic community of the Wadden Sea with the number of parasite taxa being three-times higher than the species number of their hosts. They also indicate that parasitism is a common phenomenon on molluscs of the Wadden Sea and that infection levels can be high. This makes the experimentally observed negative effects of parasites likely to actually frequently occur in the field (e.g. Wegeberg and Jensen 1999, 2003; Thieltges 2006, in press). Since most host species harbour more than one parasite species, cumulative effects are likely but these have not been investigated yet.

The effects of non-trematode parasites are still discussed. The copepod Mytilicola intestinalis has been accused to cause high mussel mortalities (Korringa 1952) but this has been questioned (Davey and Gee 1988). Also, turbellarians and nematodes might be mere commensals rather than parasites if not occurring in very high densities (Lauckner 1983). The shell boring polychaete $P$. ciliata clearly exerts negative effects and weakens the shells of bivalves and gastropods thus making the hosts more susceptible to predation (Kent 1981).

Acknowledgements We thank Dominik Kneer, Ulrike König, Georg Nehls, Britta Noll, Dörte Poszig, Penny Stoddard and Sabine Wolf for help with collecting the samples.

\section{References}

Ankel F (1962) Hydrobia ulvae Pennant und Hydrobia ventrosa Montagu als Wirte larvaler Trematoden. Videnskab Meddel Dansk Naturhist Forening Kobenhaven 124:1-99

Bartoli P, Jousson O, Russell-Pinto F (2000) The life cycle of Monorchis parvus (Digenea: Monorchiidae) demonstrated by developmental and molecular data. J Parasitol 86:479489

Borgsteede FHM, den Broek E, Swennen C (1988) Helminth parasites of the digestive tract of the oystercatcher, Haematopus ostralegus, in the Wadden Sea, The Netherlands. Netherl J Sea Res 22:171-174 
Bowers EA, Bartoli P, Russel-Pinto F, James BL (1996) The metacercariae of sibling species of Meiogymnophallus, including $M$. rebequi comb. nov. (Digenea: Gymnophallidae), and their effects on closely related Cerastoderma host species (Mollusca: Bivalvia). Parasitol Res 82:505-510

Buck BH, Thieltges DW, Walter U, Nehls G, Rosenthal H (2005) Inshore-offshore comparison of parasite infestation in Mytilus edulis: implications for open ocean aquaculture. J Appl Ichthyol 21:107-113

Cheng TC (1967) Marine molluscs as hosts for symbioses. Adv Mar Biol 5:1-424

Colautti RI, Ricciardi A, Grigorovich IA, MacIsaac HJ (2004) Is the invasion success explained by the nemy release hypothesis? Ecol Letters 7:721-733

Davey JT, Gee JM (1988) Mytilicola intestinalis, a copepod parasite of blue mussels. In: Fisher WS (ed) Diseases in marine bivalve molluscs. American Fisheries Society Special Publication 18, pp 64-73

Deblock S (1980) Inventaire des trematodes larvaires parasites des mollusques Hydrobia (Prosobranches) des Cotes de France. Parassitologia 22:1-105

Desclaux C, Mondaudouin de X, Bachelet G (2004) Cockle (Cerastoderma edule) population mortality: the role of the digenean parasite Himasthla quissetensis. Mar Ecol Prog Ser 279:141-150

Ehrich S, Stransky C (2001) Spatial and temporal changes in the southern species component of North Sea bottom fish assemblages. Senckenbergiana maritima 31:143-150

Gätje C, Reise K (1998) Ökosystem Wattenmeer: Austausch-, Transport- und Stoffumwandlungsprozesse. Springer, Berlin Heidelberg New York

Gregory RD, Blackburn TM (1991) Parasite prevalence and host sample size. Parasitol Today 7:316-318

Hulscher JB (1973) Burying-depth and trematode infection in Macoma balthica. Netherl J Sea Res 6:141-156

Jensen KT, Mouritsen KN (1992) Mass mortality in two common soft-bottom invertebrates, Hydrobia ulvae and Corophium volutator-the possible role of trematodes. Helgol Meeresunters 46:329-339

Kent RML (1981) The effect of Polydora ciliata on the shell strength of Mytilus edulis. J Cons Int Explor Mer 39:252-255

Korringa P (1952) Epidemiological observations on the mussel parasite Mytilicola intestinalis Steuer, carried out in the Netherlands 1952. Ann Biol 9:219-224

Krakau M, Thieltges DW, Reise K (2006) Parasites in introduced bivalves-implications for a coastal ecosystem. Biol Invasions DOI 10.1007/s105330-005-4734-8

Lauckner G (1971) Zur Trematodenfauna der Herzmuscheln Cardium edule und Cardium lamarcki. Helgol wiss Meeresunters 22:377-400

Lauckner G (1980) Diseases of mollusca: Gastropoda. In: Kinne $\mathrm{O}$ (ed) Diseases of marine animals vol. I General aspects, Protozoa to Gastropoda. Wiley, New York, pp 311-424

Lauckner G (1983) Diseases of Molusca: Bivalvia. In: Kinne O (ed) Diseases of marine animals vol. 2 Introduction, Bivalvia to Scaphopoda. Biologische Anstalt Helgoland, Hamburg, pp 477-961

Loos-Frank B (1967) Experimentelle Untersuchungen über Bau, Entwicklung und Systematik der Himasthlinae (Trematoda, Echinostomatidae) des Nordseeraumes. Zeitsch Parasitenk 28:299-351

Loos-Frank B (1968) Der Entwicklungszyklus von Psilostomum brevicolle (Creplin, 1829) (Syn.: P. platyurum (Mühling, 1896)) (Trematoda, Psilostomatidae). Zeitsch Parasitenk 31:122-131
Loos-Frank B (1969) Zur Kenntnis der gymnophalliden Trematoden des Nordseeraumes I. Die alternativen Zyklen von Gymnophallus choledochus Odhner, 1900. Zeitsch Parasitenk 32:135-156

Loos-Frank B (1970) Zur Kenntnis der gymnophalliden Trematoden des Nordseeraumes II. Lacunovermis macomae (Lebour, 1908) n. comb. (Syn.: Gymnophallus macroporus Jameson and Nicoll, 1913) und seine Metacercarie. Zeitsch Parasitenk 35:130-139

Loos-Frank B (1971a) Zur Kenntnis der gymnophalliden Trematoden des Nordseeraumes IV. Übersicht über die gymnophaliden Larven aus Mollusken der Gezeitenzone. Zeitsch Parasitenk 36:206-232

Loos-Frank B (1971b) Zur Kenntnis der gymnophalliden Trematoden des Nordseeraumes III: Gymnophallus gibberosus n. sp. und seine Metacercarie. Zeitsch Parasitenk 35:270281

Loos-Frank B (1971c) Zur Trematodenfauna der Silbermöwe (Larus argentatus) an der südlichen Nordsee. Vogelwarte 26:202-212

Maillard C (1975) Labratrema lamirandi (Carrere, 1937) (Trematoda, Bucephalidae) parasite de Dicentrarchus labrax (L., 1758). Creation du genre Labratrema. Cycle evolutif. Bull Mus Nat Nat Hist Naturell 193:69-80

Michaelis H (1978) Zur Morphologie und Ökologie von Polydora ciliata und P. ligni (Polchaeta, Spionidae). Helgol wiss Meeresunt 31:102-116

de Montaudouin X, Kisielewski I, Bachelet G, Desclaux C (2000) A census of macroparasites in an intertidal bivalve community, Arcachon Bay, France. Oceanol Acta 23:453-468

Mouritsen KN, Jensen KT (1994) The enigma of gigantism: effect of larval trematodes on growth, fecundity, egestion and locomotion in Hydrobia ulvae (Pennant) (Gastropoda: Prosobranchia). J Exp Mar Biol Ecol 181:53-66

Mouritsen KN, Poulin R (2002) Parasitism, communitry structure and biodiversity in intertidal ecosystems. Parasitology 124:101-117

Pechenik JA, Fried B, Simpkins HL (2001) Crepidula fornicata is not a first intermediate host for trematodes: who is? J Exp Mar Biol Ecol 261:211-224

Perry AL, Low PJ, Ellis JR, Reynolds JD (2005) Climate change and distribution of marine fishes. Science 308:1912-1915

Reimer L (1970) Digene Trematoden und Cestoden der Ostseefische als natürliche Fischmarken. Parasitol Schriftenreihe 20:1-144

Reise K (1985) Tidal flat ecology. Springer, Berlin Heidelberg New York

Reise K, Herre E Sturm M (1994) Biomass and abundance in intertidal sediments of Königshafen in the northern Wadden Sea. Helgol Meeresunters 48:201-215

Reise K, Gollasch S, Wolff WJ (1999) Introduced marine species of the North Sea coasts. Helgol Meeresunt 52:219-234

Sannia A, James BL, Bowers EA (1978) The morphology of Cercaria cerastoderma I nom. nov. (Monorchiidae) (=Cercaria lepidapedon rachion (Cobbold, 1858) sensu Lebour, 1908) a rare digenean parasite of the cockle in Britain. J Nat Hist 12:487-500

Sindermann CJ (1990) Principle diseases of marine fish and shellfish. Diseases of marine shellfish, vol 2. Academic, New York

Sousa WP (1991) Can models of soft-sediment community structure be complete without parasites? Am Zool 31:821830

Strasser M (1999) Mya arenaria - an ancient invader of the North Sea coast. Helgol Meeresunters 52:309-324 
Swennen C, Ching HL (1974) Observations on the trematode Parvatrema affinis, causative agent of crawling tracks of Macoma balthica. Netherl J Sea Res 8:108-115

Thieltges DW (2006) Impact of metacercarial trematode infections (Renicola roscovita) on growth in intertidal blue mussels (Mytilus edulis). Mar Ecol Prog Ser (in press)

Thieltges DW, Hussel B, Baekgaard H (2006) Endoparasites in common eider Somateria mollissima from birds killed by an oil spill in the northern Wadden Sea. J Sea Res 55:301-308

Torchin ME, Lafferty KD, Kuris AM (2002) Parasites and marine invasions. Parasitology 124:137-151

Wegeberg AM, Jensen KT (1999) Reduced survivorship of $\mathrm{Hi}$ masthla (Trematoda, Digenea) - infected cockles (Cerastoderma edule) exposed to oxygen depletion. J Sea Res 42:325-331
Wegeberg AM, Jensen KT (2003) In situ growth of juvenile cockles, Cerastoderma edule, experimentally infected with larval trematodes (Himasthla interrupta). J Sea Res 50:37-43

Werding B (1969) Morphologie, Entwicklung und Ökologie digener Trematoden-Larven der Strandschnecke Littorina littorea. Mar Biol 3:306-333

Yamaguti S (1958) Systema Helminthum. Digenetic trematodes. Vol 1, Part 1. Interscience Publisher, New York

Yamaguti S (1975) A synoptical review of life histories of digenetic trematodes of vertebrates. Keigaku, Tokyo

Zander CD, Reimer L (2002) Parasitism at the ecosystem level in the Baltic Sea. Parasitology 124:119-135 